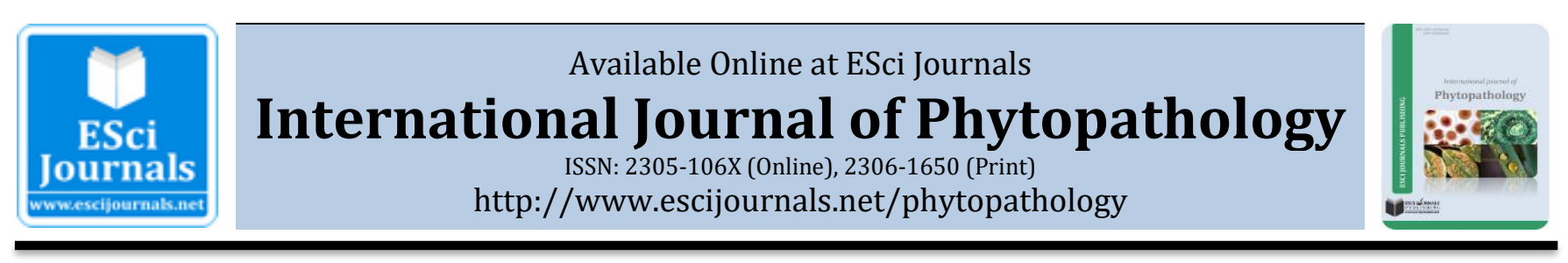

\title{
A NOVEL NEMATICIDE FOR THE CONTROL OF ROOT-KNOT NEMATODES IN TOMATO CROP
}

\author{
José A. Calvo-Araya \\ Escuela de Ciencias Agrarias, Universidad Nacional de Costa Rica.
}

\section{A B S T R A C T}

A novel nematicide (fluensulfone) was evaluated for control of the root-knot nematode Meloidogyne incognita in tomato crop (Solanum lycopersicum L.) under field conditions. The experiment was set up in a randomized complete block design with four replicates. Six treatments were assessed for control of $M$. incognita: four doses of fluensulfone, one dose of the nematicide oxamyl, and a control with no application of nematicides. Ten days before transplanting, nematicides were applied in a single application via an irrigation system. The lowest final population densities of $M$. incognita in tomato crop were recorded in plots treated with fluensulfone at the dose of $2.75 \mathrm{~L} \cdot \mathrm{ha}^{-1}$, with an average of 26 juveniles. The higher percentage of efficacy was obtained with the application of fluensulfone at a dose of $2.5 \mathrm{~L} \cdot \mathrm{ha}^{-1}$. Fluensulfone exerted a more efficient nematicidal activity as compared with oxamyl, which is the most used nematicide in crops in Mexico. Our results indicated that fluensulfone can be used as an alternative nematicide for the control of $M$. incognita in tomato crop and other crops.

Keywords: Meloidogyne incognita, fluensulfone, field conditions.

\section{INTRODUCTION}

One of the main limiting factors to the production of vegetables such as tomato (Solanum lycopersicum L.), are plant-parasitic nematodes, which can cause production losses equivalent to about $\$ 77$ to 125 billion (Abawi and Widmer 2000; Chitwood, 2003). The most important plant-parasitic nematodes affecting tomato crop belong to the genus Meloidogyne (Goldi, 1892) that is known as root knot nematode. Netscher and Sikora (1990) reported losses of $24 \%$ to $33 \%$ in tomato yield worldwide due to Meloidogyne spp. infection. Tomato crop is relevant because is the eleventh most widely grown crop in the world with a total of 159.02 million tons, from 4.73 million ha harvested in 2011. Tomato production in Mexico is especially important since this country is ranked eleventh in the world as a producer of this vegetable (FAO, 2015).

Most of the root knot nematodes are currently controlled by broad spectrum nematicides, among these, the organophosphates and carbamates such as ethoprop,

* Corresponding Author:

Email: josealonsocalvoaraya@gmail.com

(C) 2017 ESci Journals Publishing. All rights reserved. fenamiphos, fosthiazate and oxamyl are commonly used. However, most of these nematicides are acetylcholine inhibitors, with potentially toxic effects on organisms, including humans. Additionally, these nematicides can cause negative environmental impacts on ecosystems. For these reasons, their use will be banned or restricted in the future (Kearn et al., 2014). Some of these nematicides are considered to be 'nematostatics' because, at the recommended application doses, they paralyze nematodes, or affect different aspects of nematode behavior, but they do not kill them. Often, nematodes that are paralyzed by the substances recover after removal of the nematicide, become mobile and probably infective (Oka et al., 2012).

The nematicide Fluensulfone [5-chloro-2-(3,4,4trifluoro-but-3-ene-1-sulfonyl)-thiazole], which belongs to the fluoroalkenyl group, exhibits efficient nematicidal activity and a far lower toxicity to vertebrates than organophosphate- or carbamate-based nematicides. The acute $\mathrm{LD}_{50}$ of fluensulfone to rats via oral administration is more than $500 \mathrm{mg} \mathrm{kg}^{-1}$, in contrast, the $\mathrm{LD}_{50}$ for popular nematicides such as aldicarb, fenamiphos, oxamyl, cadusafos, and fosthiazate are much lower; $0.5-1.5,2-19$, 
5.4, 37.1 and $73 \mathrm{mg} \cdot \mathrm{kg}^{1}$ respectively (Oka et al., 2009, Oka et al., 2012, Oka, 2014).

Although some fluoroalkenyl compounds have shown nematicidal activity, no nematicide of this chemical family has been released in Mexico. In previous studies carried out by the present authors, fluensulfone displayed true nematicidal, rather than nematostatic activity, which is desirable (Calvo-Araya and OrozcoAceves, 2016). Fluensulfone is a contact nematicide that is applied via direct soil application and it is used for protecting a range of crop plants from plant-parasitic nematodes damage and infestation. Studies have shown that fluensulfone has direct nematicidal activity against a number of plant-parasitic nematodes, including Meloidogyne spp., Xiphinema index, Pratylenchus penetrans and P. thornei (Oka et al., 2009, Oka et al., 2012, Oka, 2014).

Experiments in growth chambers, field microplots and commercial fields also indicated an efficient nematode control by fluensulfone, which was even better than commercial nematicides widely used against root-knot nematodes (i.e., Meloidogyne incognita Kofoid \& White, 1919) (Chitwood, 1949).

In Mexico, only oxamyl is labeled for nematode control in tomato crop, therefore it is critical to provide more nematicide options to growers. Fluensulfone can be a good chemical alternative to control root-knot nematodes in commercial tomato, but its efficacy has to be tested. For this reason, our objectives were: (i) to determine the effects of fluensulfone on infection of tomato roots by $M$. incognita and the subsequent population development and, (ii) to evaluate the biological effectiveness of fluensulfone against $M$. incognita in tomato crop under field conditions.

\section{MATERIALS AND METHODS}

Location and Site Description: The research was carried out at a commercial tomato farm infested with $M$. incognita. The farm was located in Silao, Guanajuato, in Mexico. The soil within the farm was a sandy clay loam ( $56 \%$ sand, $30 \%$ clay, $14 \%$ silt), with $\mathrm{pH}$ of 6.7 . The annual rainfall in the area ranges between 600 and 800 $\mathrm{mm}$, temperature ranges from 5 to $24^{\circ} \mathrm{C}$, with $68 \%$ of relative humidity.

Experimental Design: A randomized complete block design was used for the experiment. The experimental units consisted of rows of $15 \mathrm{~m}$ long and $0.8 \mathrm{~m}$ wide, equivalent to $12 \mathrm{~m}^{2}$. The experimental design consisted of 6 treatments (4 fluensulfone doses + one oxamyl dose + control with no nematicide) $\times 4$ replicates $=24$ experimental units that represented a total of $288 \mathrm{~m}^{2}$. Specifically, the six treatments that were applied to the experimental units were: 1 ) Nimitz ${ }^{\circledR}$ (fluensulfone) at four doses $\left.\left(2.0,2.25,2.5,2.75 \mathrm{~L} \cdot \mathrm{ha}^{-1}\right), 2\right)$, Vydate $\mathrm{L} \AA$ (oxamyl) at the commercial dose of $3 \mathrm{~L} \cdot \mathrm{ha}^{-1}$, and 3) control without application of nematicides. Nematicides were applied ten days prior to transplanting via drip irrigation system.

During the experiment the plants were fertilized via irrigation system with Nitrofoska ${ }^{\circledR}$ (N-P-K (13-40-13) at a dosage of $25 \mathrm{Kg} \mathrm{ha}^{-1}$, and watered every day to field capacity via drip irrigation system. Control of pests, diseases, and weeds was made according to the recommendations of local growers, avoiding the application of products with nematicide action. The tomato variety used for the experiment was Pony Express.

\section{Response Variables}

Initial and final population densities: Ten soil samples at a depth of $15-20 \mathrm{~cm}$ from each experimental unit were collected to form a composite sample of about one kilogram per each one of the four replications = four samples per treatment. All were processed to extract and quantify the number of juveniles (J2) of M. incognita by Cobb's method (Cobb, 1918). The initial assessment was made before treatments application and the final evaluation was made 80 days after transplantation of tomato seedlings.

Percentage of galled roots: Ten plants from each experimental unit (40 plants per treatment) were extracted using a shovel, the root system was observed to calculate the percentage of galled roots per plant by using the following formula:

$$
P G R=\frac{N A R}{T R} \times 100
$$

Where: PGR= Percentage of galled root; NRA= Number of galled roots; $\mathrm{TR}=$ Total roots

Efficacy of nematicides against Meloidogyne incognita: Once the percentage of galled root was calculated, the next formula was applied to determine the efficacy of nematicide treatments:

$$
T E=\frac{G C-g t}{G C} \times 100
$$

Where TE: Treatment efficacy; GC: Percentage of galled 
root in the control; gt: Percentage of galled root in the treatments.

Plant parameters: The following plant parameters were measured: plant height (40 plants per treatment), and fresh root weight (20 plants per treatment).

Statistical Analysis: The data were analyzed by Analysis of Variance (ANOVA) using SAS statistical software version 9.2. If necessary, the means were compared by Tukey's protected least significant difference test at $(P$ $\leq 0.05$ ).

\section{RESULTS}

Initial and final population densities: The initial population densities of $M$. incognita were low and uniform, the populations did not differ across plots (i.e., not significantly different). The number of nematodes ranged from 1 to 6 individuals (J2) in $100 \mathrm{~g}$ of soil (Table 1). Final population densities of $M$. incognita ranged from 26 to $65.75 \mathrm{~J} 2$ in $100 \mathrm{~g}$ of soil (Table 1), and were significantly different $(P \leq 0.05)$ according to treatments. Plots treated with all doses of fluensulfone had significantly lower numbers of nematodes as compared with control plots and with plots treated with oxamyl (Table 1). The lowest numbers of nematodes were found in plots treated with fluensulfone at doses of 2.75 and $2.5 \mathrm{~L} \cdot h a^{-1}$. In these plots, 26 and $28.5 \mathrm{~J} 2$ were observed respectively.

Table 1. Initial (Ip) and final (Fp) population densities of Meloidogyne incognita (number of J2 in $100 \mathrm{~g}^{-1}$ 'soil) found in plots treated with fluensulfone at different doses, and oxamyl (commercial control). Plots with no application of nematicides acted as absolute controls.

\begin{tabular}{ccccc}
\hline Treatment & Nematicide & Dosage $\left(\right.$ Lha $\left.^{-1}\right)$ & Ip & Fp \\
\hline 1 & Oxamyl & 3.0 & $2.00^{\mathrm{a}}$ & $41.75^{\mathrm{b}}$ \\
2 & Fluensulfone & 2.0 & $2.50^{\mathrm{a}}$ & $32.75^{\mathrm{c}}$ \\
3 & Fluensulfone & 2.25 & $2.25^{\mathrm{a}}$ & $29.75^{\mathrm{c}}$ \\
4 & Fluensulfone & 2.5 & $2.00^{\mathrm{a}}$ & $28.25^{\mathrm{c}}$ \\
5 & Fluensulfone & 2.75 & $2.00^{\mathrm{a}}$ & $26.00^{\mathrm{c}}$ \\
6 & No nematicide & - & $2.50^{\mathrm{a}}$ & $65.75^{\mathrm{a}}$ \\
\hline
\end{tabular}

Means followed by the same letters in each column are not significantly different $(P \leq 0.05)$.

Percentage of galled roots: Values for the percentage of galled roots significantly differed $(P \leq 0.05)$ according to nematicide treatments (Table 2). Tomato plants grown in control plots had the highest rates of infection (47\%), while plants grown in plots treated with fluensulfone at doses of 2.0, 2.5 and $2.75 \mathrm{~L} \cdot \mathrm{ha}^{-1}$ displayed roots with reduced percentage of galled roots as compared with controls (i.e., 8.5, 8.0 and 9.0\% respectively). However, fluensulfone treatments did not differed as compared with oxamyl treatment (Table 2).
Efficacy of nematicides against $M$. incognita: The efficacy of nematicides did not significantly differ across treatments, including controls with no application of nematicide (Figure 1).

\section{Plant growth parameters}

Height and fresh root weight of tomato plants showed no statistical differences according to nematicide treatments that included controls with no application of nematicide (Table 3).

Table 2. Percentage of galled roots (PGR) observed in tomato plants grown in plots treated with fluensulfone at different doses, and oxamyl (commercial control). Plots with no application of nematicides acted as absolute controls.

\begin{tabular}{cccc}
\hline Treatment & Nematicide & Dosage $\left(\mathrm{L} \cdot \mathrm{ha}^{-1}\right)$ & PGR \\
\hline 1 & Oxamyl & 3.0 & $14.00 \mathrm{~b}$ \\
2 & Fluensulfone & 2.0 & $8.50 \mathrm{~b}$ \\
3 & Fluensulfone & 2.25 & $14.50 \mathrm{~b}$ \\
4 & Fluensulfone & 2.5 & $8.00 \mathrm{~b}$ \\
5 & Fluensulfone & 2.75 & $9.00 \mathrm{~b}$ \\
6 & No nematicide & - & $47.00 \mathrm{a}$ \\
\hline
\end{tabular}

Means followed by the same letters in each column are not significantly different $(P \leq 0.05)$. 


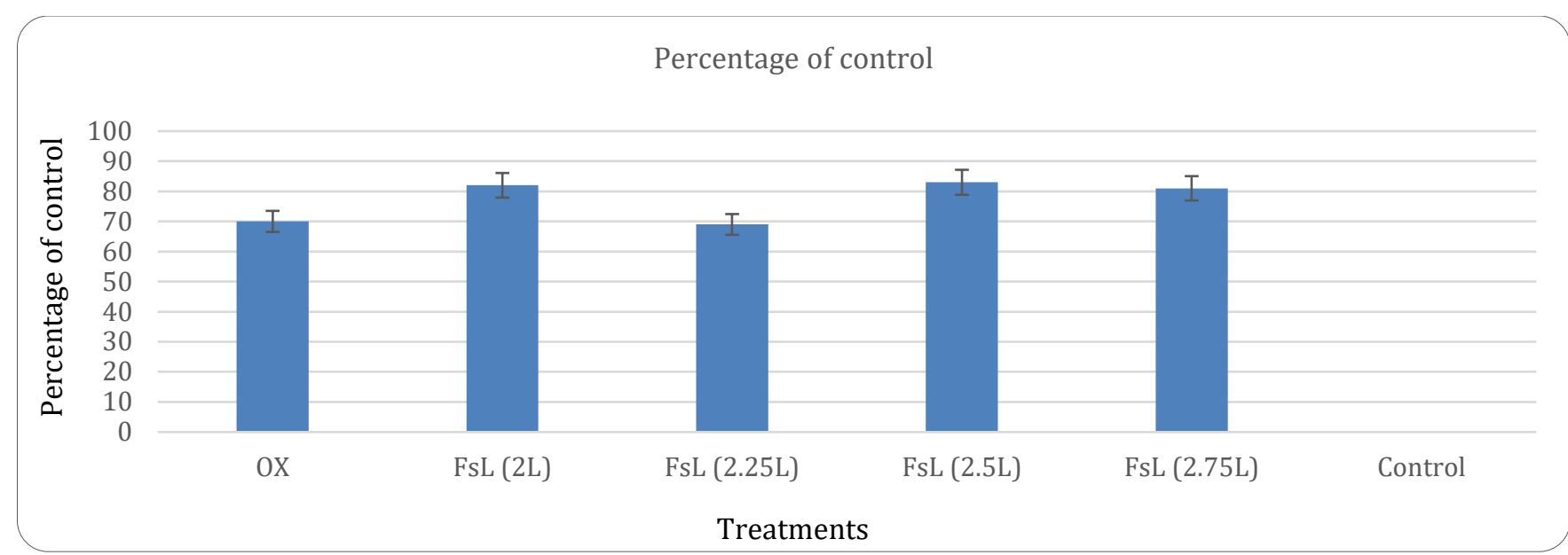

Figure 1. Percentages of efficacy of the nematicide fluensulfone (Fsf) at different doses, and oxamyl (OX) against Meloidogyne incognita in tomato plants. Means followed by the same letters in each bar are not significantly different $(P \leq 0.05)$.

Table 3. Height $(\mathrm{H})$ and fresh root weight (FRW) of tomato plants grown in soils treated with different doses of fluensulfone, and oxamyl (commercial control). Plots with no application of nematicides acted as absolute controls.

\begin{tabular}{ccccc}
\hline Treatment & Nematicide & Dosage $\left(\mathrm{L} \cdot \mathrm{ha}^{-1}\right)$ & $\mathrm{H}$ & FRW \\
\hline 1 & Oxamyl & 3 & $64.30 \mathrm{a}$ & $43.80 \mathrm{a}$ \\
2 & Fluensulfone & 2 & $72.80 \mathrm{a}$ & $45.20 \mathrm{a}$ \\
3 & Fluensulfone & 2.25 & $67.80 \mathrm{a}$ & $44.10 \mathrm{a}$ \\
4 & Fluensulfone & 2.5 & $64.80 \mathrm{a}$ & $43.20 \mathrm{a}$ \\
5 & Fluensulfone & 2.75 & $65.30 \mathrm{a}$ & $40.80 \mathrm{a}$ \\
6 & No nematicide & - & $68.30 \mathrm{a}$ & $44.20 \mathrm{a}$ \\
\hline
\end{tabular}

Means followed by the same letters in each column are not significantly different at $P<0.05$.

\section{DISCUSSION}

From the parameters that were measured during this research, only the final population in soil of $M$. incognita was significantly reduced by application of fluensulfone in comparison with oxamyl and controls. The percentage of galled roots was significantly reduced in plots treated with fluensulfone as compared with controls, but no differences in this parameter were observed as compared with oxamyl, which is the most used nematicide in horticultural crops in Mexico. These results are positive, because evidenced the possibility to obtain an acceptable control of M. incognita in tomato by using a less toxic nematicide (i.e., fluensulfone), as compared with highly toxic oxamyl.

The initial populations of $M$. incognita in soils were low at the starting point of the experiment. This finding is expected since the initial nematode population was quantified prior to planting, and at this point in time there was absence of host plants. Meloidogyne incognita is an endoparasite, which means that it needs a suitable host plant to complete its life cycle, in absence of crops or suitable hosts, nematode population tends to be low (Hutton, 1993).

Final population densities of $M$. incognita increased over time, a result that was expected due to the presence of suitable hosts (i.e., tomato plants) and favorable conditions of humidity and temperature (Poveda, 1991). Populations of $M$. incognita in control plots (with no nematicide applied) increased normally because these organisms were not exposed to detrimental factors (no nematicides) and found susceptible plant hosts as food source. The numbers of $M$. incognita were lower in soils treated with all fluensulfone doses as compared with oxamyl. Oxamyl is a carbamate, which act as nematostatic at low concentrations and short exposure periods (Thomason, 1985). This nematicide can paralyze plantparasitic nematodes, affecting some aspects of their behavior, such as orientation and hatching, but the 
substance does not kill the organisms (Wright et al., 1980; McGarvey et al., 1984; Thomason, 1985; Cavelier, 1987, Opperman and Chang, 1990), which is a disadvantage in comparison with other nematicides, including fluensulfone.

The results of final population densities of $M$. incognita evidenced that fluensulfone exerted a detrimental effect on nematode populations, preventing their increase in soil to levels that could generate significant damage to crop, thereby giving good protection during the susceptible crop stage. Fluensulfone displays some advantages over other nematicides, for example, it has activity against Meloidogyne spp. both pre- and postinvasion that is given by diverse action modes of the substance on nematode biology (general paralysis, inhibition of juvenile motility in the root, inhibition of feeding site formation or stylet behavior, diminished host-finding capability, inhibition of egg laying and the subsequent hatching of these eggs) (Angelo and Van Gilst, 2009; Oka et al., 2009; Oka et al., 2012).

In this study fluensulfone prevented root galling (as compared with controls with no application of nematicide). Root galls are only formed when Meloidogyne spp. have entered the host and induced the formation of nurse cells (Oka et al., 2009). For this reason, it is probable that fluensulfone prevented the juveniles from invading the host plant, or inhibited the induction of nurse cells, or prevented the maturation and development of plant-parasitic nematodes inside the host (Oka et al., 2009, Oka et al., 2012). No differences in percentage on galled roots were observed when comparing fluensulfone doses with oxamyl. However, this result is positive because evidenced a similar control effect of fluensulfone as compared with the most used nematicide; oxamyl.

Despite our results indicated significant differences in parameters associated with nematode infection (i.e., final population density of $\mathrm{J} 2$ in soil, and the percentage of galled roots) according to nematicide treatments, these findings did not translate into significant differences in plant parameters (i.e., height and fresh root weight). We could attribute this phenomenon to: 1) low initial populations of $M$. incognita at the starting point of the experiment, and 2) an adequate fertilization of tomato plants. These hypotheses raise two important agronomical good practices useful in the control of plantparasitic nematodes: 1) an adequate nematode monitoring is necessary, in order to apply nematicide only if population densities increase, and 2) good fertilization practice that can partially offset $M$. incognita damage in tomato crop by stimulating plant development (Asano and Moura, 1995; Huber and Wilhelm, 1995). On the other hand, nitrogen in the ammonium form, present in fertilizers, might have a negative effect on nematodes due to its plasmolytic effect around the point at which it is applied to the soil (Asano and Moura, 1995).

\section{CONCLUSION}

The present research revealed that application of fluensulfone under experimental conditions in tomato crop provided an acceptable control of $M$. incognita (as compared with controls with no nematicide application) that was better (lower final population densities of $M$. incognita and lower percentages of galled roots) or similar (no differences in nematicide efficacy) as compared with oxamyl, which is the most common nematicide used in tomato production in Mexico. According to results, doses of $2.5-2.75 \mathrm{~L}^{-\mathrm{ha}^{-1}}$ are adequate to control $M$. incognita. These doses are lower as compared with commercial dose of oxamyl $\left(3 \mathrm{~L} \cdot \mathrm{ha}^{-1}\right)$. For these reasons, fluensulfone can be considered an alternative nematicide for the control of $M$. incognita in tomato crop, with advantages (over oxamyl) of displaying diverse action modes and being less toxic (to non-target organisms, including humans) and consequently of lower environmental impact. Further evaluation of this nematicide has to be carried out in different crops to evaluate its nematicidal properties against other plantparasitic nematodes under commercial field conditions.

\section{REFERENCES}

Abawi GS, Widmer TL, 2000. Impact of soil health management practices on soilborne pathogens, nematodes and rood diseases of vegetable crops. Applied Soil Ecology 15: 37-47.

Abbott WS, 1925. A method of computing the effectiveness of an insecticides. Journal of Economic Entomology 18: 265-267.

Asano S, Moura RM, 1995. Efeitos dos macro e micronutrientes na severidade da meloidoginose da cana de açúcar. Nematol. Bras. 19:15-20.

Cabrera- Hidalgo. 2014. Nacobbus aberrans en cultivos hortícolas del Centro del Bajío, México: Distribución, abundancia y caracterización molecular. Mexico: Colegio de Postgraduados, PhD thesis.

Calvo-Araya, J.A. and Orozco-Aceves, M. 2016. Nematicidal efficacy of Fluensulfone against false 
root-knot nematode (Nacobbus aberrans) in cucumber crop under field conditions. Journal of Experimental Agriculture International 14:1-8

Cavelier A, 1987. Le mode d'action des nematicidas nonfumigants. Agronomie 7(10):747-762.

Chitwood DJ, 2003. Research on plant-parasitic nematode biology conducted by the United States Department of Agriculture- Agricultural Research Service. Pest Management Science 59: 748-753.

Cobb NA, 1918. Estimating the nema population of the soil. Washington, United States Department of Agriculture (Agricultural Technical Circular, 1).

FAO. 2015. Statistics Division of FAO (Online). [http://faostat.fao.org]. Accessed 20 December 2015.

Huber DM, Wilhelm NS, 1988. The role of manganese in resistance to plant diseases. In: Graham RD, Hannan RJ, Uren NC, eds. Proceedings of the International Symposium on on Manganese in soils and plants. Kluwer Academic. Dordrecht, The Netherlands. 157-168.

Hutton DG, 1993. Recognizing and Controlling Nematode Damage on Some Crops Grown in Jamaica. Hyde, Held \& Blackburn. Kingston, Jamaica. 52 p.

Langston DB, Sanders FH, 2011. Reducing damage to root-knot nematode with fluensulfone (formerly thiazosulfene) in cucumbers and peppers. Phytopathology 101: S97-S98.

McGarvey BD, Potter JW, Chiba M, 1984. Nematostatic activity of oxamil and $\mathrm{N}, \mathrm{N}$ dimethyl-1cyanoformamide (DMCF) on Meloidogyne incognita juveniles. Journal of nematology 16(3):328-332

Netscher C, Sikora RA. 1990: Nematodes parasites of vegetables. In: Luc, M.; Sikora RA, Bridge J. eds. Plant Parasitic Nematodes in Subtropical and Tropical Agriculture. CABI. International. London, UK. 237-283

Oka YS, Shuker N, Tkachi, N, 2012. Systemic nematicidal activity of fluensulfone against the root-knot nematode Meloidogyne incognita on pepper, Pest Management.Science. 68:268-275.

Oka Y, Shuker S, Tkachi N, 2009. Nematicidal efficacy of MCW-2, a new nematicide of the fluoroalkenyl group, against the root-knot nematode Meloidogyne javanica. Pest Management Science 65: 1082-1089.

Opperman, C. H., and S. Chang. 1990. Plant parasitic nematode acetylcholinesterase inhibition by carbamate and organophosphate nematicidas. Journal of nematology 22(4):481-488.

PovedaJ. 1991. Determinación de la distribución y frecuencia de fitonematodos asociados al cultivo de melón (Cucumis melo L.) y evaluación de tácticas para combatir Meloidogyne incognita (Kofoid \& White) (Chitwood) en la región de Azuero, Panamá. Tesis de Magister Scientiae. Turrialba, Costa Rica. 92 p.

SAS Intitute. User' guide. The SAS System software for Windows release 9.0. SAS Institute, Cary N.C. USA; 2002.

Taye, W; Sakhuja, P. K; Tadele Tefera, T. 2012. Evaluation of plant extracts on infestation of root-knot nematode on tomato (Lycopersicon esculentum Mill). E3 Journal of Agricultural Research and Development 2 (3): 086-091.

Taylor, A.; Sasser, J. 1978. Biology, identification and control of rootknot nematode (Meloidogyne species). Cooperative Publication of the Department of Plant Pathology. North Carolina State University and the United States Agency for International Development. $911 \mathrm{p}$.

Thomason, I. J. 1985. Nematicides. Pp. 235-257. In: Marbán-Mendoza, N, and Thomason, I. J. (eds.). Fitonematología avanzada I. COLPOS, Montecillo, Estado de México. México.

Wright, D.J., A. R. K. Blyth, and P. E. Pearson. 1980. Behaviour of the systemic nematicide oxamy in plants in relation to control of invasion and development of Meloidogyne incognita. Annals of Applied Biology 96: 323-334. 